\title{
Causes, Impact of Noises with Remedies in Rathinamangalam, Tamilnadu, India
}

\section{J.S. Sudarsan, A.Arthy, S. Nithiyanantham, M.G.Prathap}

\begin{abstract}
The noise pollution is one of the slow killer and The pollution level increasing day by day mostly in Industrial areas, heavy traffic, markets, theatre, and etc., mainly in metropolitan cities and municipalities in the developing countries. In this research study the noise pollution analysis in quarry mining area was carried out in Rathinamangalam, Tamilnadu, India. Further, the causes of Noise Impact was also studied and analyzed. Mainly the health effects were studied. The measurement of sound was made by Sound level meter for period of one year the impact of pollution was also observed on the biotic components. The noise pollution in the very close vicinity of quarry site was higher than the prescribed guidelines especially in the sensitive and residential zone areas. The noise pollution sampling was carried at different seasons, timings and the results are tabulated and compared With Central Pollution Control Board (CPCB) guidelines. Suitable remedial Measures also suggested for controlling the same.
\end{abstract}

Keywords: Quarry Mining, Noise Pollution, Sound Level Meter, Health Effects.

\section{INTRODUCTION}

Due to urbanization, over population, automobiles, industries, causes noise pollution in over the globe mainly China and India [1]. The emission of particulate matter from quarry has been assessed in the vicinity. Particulates are emitted due to quarrying, aggregate crusher, abrasive blaster, unsealed surfaces and material stock piles $[2,3]$.

Mining is the technique by which we extract resources from the earth. There are different types of mining. Mining can generally be divided into surface and subsurface (underground) mining [4]. The choice of surface or subsurface mining method depends on different factors like economic, geologic, engineering and other factors. One of the most widely used mineral resources is construction materials from surface mining operations which are extracted by quarrying method [5].

Revised Manuscript Received on December 05, 2019.

J.S.Sudarsan, National Institute of Construction Management and Research (NICMAR),25/1, Balewadi, Pune,411045, India.

A.Arthy, Environmental consultant(Freelancer).

S. Nithiyanantham, Post Graduate and Research Department of Physics, Thiru.Vi.Kalyanasundaram Govt Arts \& Science College, Thiruvarur, Tamilnadu, India- 610003.

M.G.Prathap, Department of Civil Engineering, Saveetha Engineering College, Thandalam, Chennai-602105, India.

Corresponding author:

sudarsanjss@yahoo.com

A quarry is generally used for extracting construction materials like dimension stone, ornamental stones, Coarse aggregate, fine aggregate road building and industrial raw materials. Since all the activities in the urban centers depend on materials from earth, especially quarrying and their related activities are located near population centers, industries, temples and educational institutions [6].

The quarry is the set up for crushing rock pieces into small fragments and it necessary for human use. But, it causes noise pollution, air pollution and etc. Noise pollution caused mainly during blasting, processing of quarried materials and transportation of the materials So, it is necessary to reduce the noise from quarries. The impact of noise pollution, destruction of natural beauty, destruction of habitats, creating health impact to the people employed and the in the nearby village community if not controlled it will have adverse impact on infant, elderly people and women. The noise pollution is high also the emissions of particulate matter also high in the quarrying site [7, 8]. The CPCB Manual- specifies measures and guidelines to control the noise pollution as per the specifications of noise pollution control act of India [12]. The aim of this work is to assess the amount of noise pollution present in the Rathinamangalam quarrying area and mitigative measures to reduce the same.

\section{IMPACTS}

The types of impacts are noise and environmental impacts. National guidance aimed at achieving sound mitigation and consistent decisions on dust management and noise pollution and control. It also helps in creating a platform in handling the situation judicially and highlight the responsibilities of local and regional authorities in achieving the same $[4,5,11]$.

\section{MATERIALS AND METHODOLOGY}

Site Selection: Quarrying site located in Rathinamangalam near Vandalur, northeast of Kanchipuram District, Tamil nadu; India has been selected for collecting sample. Since vandalur being a zone of reserved forest and Wild life sanctuary and Zoo also located in that area, The noise pollution study measurement from the quarrying is vital for considering any environmental mitigation measures. Sampling has been done around the quarrying site to quantify the level of noise pollution. Data collected as per the guidelines of CPCB manual [1,9].

Sampling Frame Work: Primary data collection: Data collected initially at the sampling site for air and noise quality monitoring using high volume sampler provides effective impacts analysis. Primary data collected is compared with national air quality standards for effective comparison. 
Secondary data collection: Data collected under this supports primary data which includes meteorological data to know the rainfall intensities. The supplements data the study by providing more detailed knowledge about it. For instance, this helps in the health risk assessment and hazard risk assessment.

\section{ANALYSIS}

Sound Level Meter: The sound level meter was used to take the noise level at different sampling location during different seasons and periods The intensity of noise in and around the Rathinamangalam area were recorded and calculated. About 11 sampling locations were selected. Sampling points are considered based on residential, commercial and sensitive zone. In each zone a representative sampling was carried out like colleges, temple, hospital and rural area are included in the sampling locatioons. Sampling is been taken in the time intervals of peak hours morning 8-10am and evening 4-6pm (3). The readings are noted and calculated using Equivalent noise level equation (1) [13].

$$
\mathrm{L}_{\mathrm{eq}}=10 \log _{10}\left(\frac{\left[\sum_{i=1}^{n}\left(t_{i} * 10^{0.1} S P L_{i}\right)\right]}{2}\right)
$$

Where, $\mathrm{I}=$ is a discrete activity of a worker exposed to a sound level, $\mathrm{Ti}=$ is the duration in hours of $\mathrm{I}, \mathrm{SPLi}=$ is the sound level of $\mathrm{i}$ in $\mathrm{dbA}, \mathrm{N}=$ is the total number of discrete activities in the total workday.

Meteorological data of the sampling are collected from the nearest Meteorological center in Chennai. The wind speed and its direction impacts on the pollution level also studied.

\section{RESULTS AND DISCUSSION}

The sampling location has been marked as 1 to 8 with the sampling site as Rathinamangalam area in that location colleges, hospital, temples and increase in urban development. The sampling points are marked and coordinates are noted and plotted in map and the readings are taken for a period of one year. The meteorological data also collected to show the impact of rainfall and wind speed and direction and its influence on pollution. The sample points are selected within the distance of $500 \mathrm{~m}$ where the samples are taken. The wind speed shows the flow of particulate matter and direction of flow. The rainfall intensity shows the reduction in concentration of pollution .

The wind flows towards the north east and the velocity of flow of wind is $3.6-5.7 \mathrm{~m} / \mathrm{s}$ in the north and $5.7-8.8 \mathrm{~m} / \mathrm{s}$ in the east. The flow of wind shows the distribution of pollution in the area.The wind speed and direction shows the distribution of noise pollution and suspended particulate matter in and around the Rathinamangalam area is high during post monsoon due the wind direction and other environmental factors.

Noise Level: Data was measured using Sound level meter in the project area and also collected surrounding of the Rathinamangalam, Kandigai, Kollapakkam and police academy. The sampling points are been noted from 1 to 11 and the co-ordinates are been plotted in the map. The readings are been collected in the peak hours from 8-10 am and $4-6 \mathrm{pm}$.

First the instrument is to set for calibration and then the readings are noted. First the exposure time is noted and the readings in that time the readings are been noted and the readings are been applied in the formulae and the final readings are plotted $[10,11]$.

Table 4. Sampling Location and Readings

\begin{tabular}{|c|c|c|c|c|}
\hline \multirow[t]{2}{*}{ S.No } & \multirow{2}{*}{$\begin{array}{l}\text { Sampling } \\
\text { Locations }\end{array}$} & \multirow[t]{2}{*}{ Date } & \multicolumn{2}{|c|}{ Noise level in $\mathrm{dB}$} \\
\hline & & & $\begin{array}{l}8 \mathrm{AM}- \\
10 \mathrm{AM}\end{array}$ & $\begin{array}{l}4 \mathrm{PM}- \\
6 \mathrm{PM}\end{array}$ \\
\hline \multirow[t]{4}{*}{1} & \multirow{4}{*}{$\begin{array}{c}\text { Police Academy } \\
\text { Lat: } 12.5217 \\
\text { Long: } 80.6367\end{array}$} & $12 / 3 / 2015$ & $75(17)$ & $69(17)$ \\
\hline & & $13 / 3 / 2015$ & $67(14)$ & $55(16)$ \\
\hline & & $14 / 3 / 2015$ & $71(18)$ & $62(13)$ \\
\hline & & $15 / 3 / 2015$ & $79(15)$ & $74(21)$ \\
\hline \multirow[t]{4}{*}{2} & \multirow{4}{*}{$\begin{array}{c}\text { Ramanujar } \\
\text { College } \\
\text { Lat:12.5210 } \\
\text { Long:80.652 }\end{array}$} & $12 / 3 / 2015$ & $72(11)$ & $70(23)$ \\
\hline & & $13 / 3 / 2015$ & $79(17)$ & $68(20)$ \\
\hline & & $14 / 3 / 2015$ & $67(14)$ & $71(18)$ \\
\hline & & $15 / 3 / 2015$ & $73(21)$ & $66(16)$ \\
\hline \multirow[t]{4}{*}{3} & \multirow{4}{*}{$\begin{array}{c}\text { Kollapakkam } \\
\text { Lat: } 12.52 \\
\text { Long: } 80.73\end{array}$} & $12 / 3 / 2015$ & $70(12)$ & $73(17)$ \\
\hline & & $13 / 3 / 2015$ & $74(19)$ & $77(10)$ \\
\hline & & $14 / 3 / 2015$ & $68(11)$ & $64(15)$ \\
\hline & & $15 / 3 / 2015$ & $80(22)$ & $70(19)$ \\
\hline \multirow[t]{4}{*}{4} & \multirow{4}{*}{$\begin{array}{c}\text { Quarry Site } \\
\text { Entrance } \\
\text { Lat: } 12.514 \\
\text { Long:80.73 }\end{array}$} & $12 / 3 / 2015$ & $67(24)$ & $70(15)$ \\
\hline & & $13 / 3 / 2015$ & $62(14)$ & $65(18)$ \\
\hline & & $14 / 3 / 2015$ & $59(19)$ & $67(12)$ \\
\hline & & $15 / 3 / 2015$ & $69(21)$ & $71(14)$ \\
\hline \multirow[t]{4}{*}{5} & \multirow{4}{*}{$\begin{array}{c}\text { Srinivasa Rao } \\
\text { Lat: } 12.52 \\
\text { Long: } 80.75\end{array}$} & $19 / 3 / 2015$ & $62(9)$ & $59(13)$ \\
\hline & & $20 / 3 / 2015$ & $55(14)$ & $60(12)$ \\
\hline & & $21 / 3 / 2015$ & $60(10)$ & $58(6)$ \\
\hline & & $22 / 3 / 2015$ & $63(15)$ & $54(12)$ \\
\hline \multirow[t]{4}{*}{6} & \multirow{4}{*}{$\begin{array}{c}\text { Kubarer Temple } \\
\text { Lat: } 12.513 \\
\text { Long: } 80.751\end{array}$} & $19 / 3 / 2015$ & $55(15)$ & $60(11)$ \\
\hline & & $20 / 3 / 2015$ & $56(10)$ & $58(18)$ \\
\hline & & $21 / 3 / 2015$ & $58(18)$ & $61(14)$ \\
\hline & & $22 / 3 / 2015$ & $63(12)$ & $59(10)$ \\
\hline \multirow[t]{4}{*}{7} & \multirow{4}{*}{$\begin{array}{c}\text { Tagore Engg } \\
\text { College } \\
\text { Lat: } 12.515 \\
\text { Long: } 80.812\end{array}$} & $19 / 3 / 2015$ & $79(18)$ & $80(22)$ \\
\hline & & $20 / 3 / 2015$ & $82(14)$ & $75(19)$ \\
\hline & & $21 / 3 / 2015$ & $72(23)$ & $79(17)$ \\
\hline & & $22 / 3 / 2015$ & $77(19)$ & $78(20)$ \\
\hline \multirow[t]{4}{*}{8} & \multirow{4}{*}{$\begin{array}{c}\text { Tagore Medial } \\
\text { College } \\
\text { Lat: } 12.513 \\
\text { Long: } 80.759\end{array}$} & $19 / 3 / 2015$ & $61(6)$ & $63(11)$ \\
\hline & & $20 / 3 / 2015$ & $58(10)$ & $54(13)$ \\
\hline & & $21 / 3 / 2015$ & $64(13)$ & $59(18)$ \\
\hline & & $22 / 3 / 2015$ & $55(14)$ & $60(10)$ \\
\hline \multirow[t]{4}{*}{9} & \multirow{4}{*}{$\begin{array}{c}\text { Tagore Medial } \\
\text { Entrance } \\
\text { Lat: } 12.514 \\
\text { Long: } 80.890\end{array}$} & $25 / 3 / 2015$ & $80(14)$ & $76(19)$ \\
\hline & & $27 / 3 / 2015$ & $75(22)$ & $78(17)$ \\
\hline & & $28 / 3 / 2015$ & $73(18)$ & $77(21)$ \\
\hline & & $30 / 3 / 2015$ & $76(15)$ & $70(16)$ \\
\hline \multirow[t]{4}{*}{10} & \multirow{4}{*}{$\begin{array}{c}\text { Kandigai IOB } \\
\text { Lat: } 12.518 \\
\text { Long: } 80.821\end{array}$} & $25 / 3 / 2015$ & $82(18)$ & $78(14)$ \\
\hline & & $27 / 3 / 2015$ & $77(17)$ & $80(21)$ \\
\hline & & $28 / 3 / 2015$ & $76(15)$ & $79(19)$ \\
\hline & & $30 / 3 / 2015$ & $79(22)$ & $77(18)$ \\
\hline 11 & Kandigai Bus & $25 / 3 / 2015$ & $80(19)$ & $76(23)$ \\
\hline
\end{tabular}




\begin{tabular}{|c|c|c|c|c|}
\hline & stand & $27 / 3 / 2015$ & $79(17)$ & $82(15)$ \\
\cline { 3 - 5 } & Lat:12.513 & $28 / 3 / 2015$ & $83(23)$ & $80(14)$ \\
\cline { 3 - 5 } & Long:80.825 & $30 / 3 / 2015$ & $78(15)$ & $79(20)$ \\
\hline
\end{tabular}

The noise level and the exposure time in the selected sampling site date of sample collection and the co-ordinates were shown in Table.4. This shows the present of noise level and equivalent noise level and the equivalent noise level is been calculated and given in the Table.5.

Table. 5. Sampling Location and Equivalent Noise level in Residential Zones

\begin{tabular}{|c|c|c|c|c|c|c|}
\hline \multirow[t]{2}{*}{$\begin{array}{l}\mathrm{S} . \\
\mathrm{N} \\
\mathrm{o}\end{array}$} & \multirow[t]{2}{*}{$\begin{array}{l}\text { Sampling } \\
\text { Locations }\end{array}$} & \multirow[t]{2}{*}{ Date } & \multicolumn{2}{|c|}{$\begin{array}{l}\text { Equivalent } \\
\text { Noise } \\
\text { Exposure } \\
\text { Level(dB) } \\
\end{array}$} & \multirow{2}{*}{\multicolumn{2}{|c|}{$\begin{array}{c}\text { Average } \\
\text { Noise } \\
\text { Level(dB } \\
\text { ) }\end{array}$}} \\
\hline & & & $\begin{array}{c}8- \\
10 \\
\text { AM }\end{array}$ & $\begin{array}{c}4-6 \\
\text { PM }\end{array}$ & & \\
\hline \multirow{4}{*}{1} & \multirow{4}{*}{$\begin{array}{c}\text { Police } \\
\text { Academy }\end{array}$} & $12 / 3 / 2015$ & 66.5 & 59.0 & \multirow{4}{*}{64} & \multirow{4}{*}{56} \\
\hline & & $13 / 3 / 2015$ & 57.7 & 46.0 & & \\
\hline & & $14 / 3 / 2015$ & 62.8 & 52.0 & & \\
\hline & & $15 / 3 / 2015$ & 70.0 & 66.0 & & \\
\hline \multirow{4}{*}{2} & \multirow{4}{*}{$\begin{array}{c}\text { Kollapakka } \\
\text { m }\end{array}$} & $12 / 3 / 2015$ & 60.0 & 64.0 & \multirow{4}{*}{64} & \multirow{4}{*}{62} \\
\hline & & $13 / 3 / 2015$ & 66.0 & 66.2 & & \\
\hline & & $14 / 3 / 2015$ & 57.6 & 55.0 & & \\
\hline & & $15 / 3 / 2015$ & 72.6 & 62.0 & & \\
\hline \multirow{4}{*}{3} & \multirow{4}{*}{$\begin{array}{l}\text { Quarry Site } \\
\text { Entrance }\end{array}$} & $12 / 3 / 2015$ & 60.0 & 61.0 & \multirow{4}{*}{56} & \multirow{4}{*}{59} \\
\hline & & $13 / 3 / 2015$ & 52.7 & 56.8 & & \\
\hline & & $14 / 3 / 2015$ & 51.0 & 57.0 & & \\
\hline & & $15 / 3 / 2015$ & 61.4 & 61.7 & & \\
\hline \multirow[t]{4}{*}{4} & \multirow{4}{*}{$\begin{array}{c}\text { Srinivasa } \\
\text { Rao }\end{array}$} & $19 / 3 / 2015$ & 50.8 & 49.3 & \multirow[t]{4}{*}{49} & \multirow[t]{4}{*}{47} \\
\hline & & $20 / 3 / 2015$ & 45.7 & 50.0 & & \\
\hline & & $21 / 3 / 2015$ & 49.2 & 45.0 & & \\
\hline & & $22 / 3 / 2015$ & 54.0 & 44.0 & & \\
\hline \multirow[t]{4}{*}{5} & \multirow{4}{*}{$\begin{array}{l}\text { Tagore } \\
\text { Medical } \\
\text { Entrance }\end{array}$} & $25 / 3 / 2015$ & 70.7 & 68.0 & \multirow[t]{4}{*}{67} & \multirow[t]{4}{*}{67} \\
\hline & & $27 / 3 / 2015$ & 67.6 & 69.5 & & \\
\hline & & $28 / 3 / 2015$ & 64.8 & 69.4 & & \\
\hline & & $30 / 3 / 2015$ & 67.0 & 61.2 & & \\
\hline \multirow[t]{4}{*}{6} & \multirow{4}{*}{$\begin{array}{c}\text { Kandigai } \\
\text { IOB }\end{array}$} & $25 / 3 / 2015$ & 73.8 & 68.7 & \multirow{4}{*}{70} & \multirow[t]{4}{*}{70} \\
\hline & & $27 / 3 / 2015$ & 68.5 & 72.4 & & \\
\hline & & $28 / 3 / 2015$ & 68.6 & 71.0 & & \\
\hline & & $30 / 3 / 2015$ & 71.6 & 68.8 & & \\
\hline \multirow[t]{4}{*}{7} & \multirow{4}{*}{$\begin{array}{l}\text { Kandigai } \\
\text { Bustand }\end{array}$} & $25 / 3 / 2015$ & 72.0 & 68.8 & 71 & 70 \\
\hline & & $27 / 3 / 2015$ & 70.5 & 73.0 & & \\
\hline & & $28 / 3 / 2015$ & 75.8 & 70.7 & & \\
\hline & & $30 / 3 / 2015$ & 69.0 & 71.2 & & \\
\hline
\end{tabular}

Table .6. Sampling location and Equipment Noise Level in Silent Zones

\begin{tabular}{|c|c|c|c|c|c|c|}
\hline \multirow{4}{*}{1} & \multirow{4}{*}{$\begin{array}{l}\text { Kubarer } \\
\text { Temple }\end{array}$} & $19 / 3 / 2015$ & 46.0 & 49.6 & \multirow{4}{*}{48.5} & \multirow{4}{*}{49.8} \\
\hline & & $20 / 3 / 2015$ & 45.2 & 49.8 & & \\
\hline & & $21 / 3 / 2015$ & 49.8 & $51 . .7$ & & \\
\hline & & $22 / 3 / 2015$ & 53.0 & 48.2 & & \\
\hline \multirow{4}{*}{2} & \multirow{4}{*}{$\begin{array}{l}\text { Tagore } \\
\text { Engg } \\
\text { College }\end{array}$} & $19 / 3 / 2015$ & 70.8 & 72.6 & \multirow{4}{*}{69.3} & \multirow{4}{*}{70.09} \\
\hline & & $20 / 3 / 2015$ & 72.7 & 67.0 & & \\
\hline & & $21 / 3 / 2015$ & 64.8 & 70.5 & & \\
\hline & & $22 / 3 / 2015$ & 69.0 & 70.2 & & \\
\hline \multirow{3}{*}{3} & \multirow{3}{*}{$\begin{array}{l}\text { Iagore } \\
\text { medical } \\
\text { college }\end{array}$} & $19 / 3 / 2015$ & 48.0 & 52.6 & \multirow{3}{*}{48.8} & \multirow{3}{*}{49.2} \\
\hline & & $20 / 3 / 2015$ & 47.2 & 44.3 & & \\
\hline & & $21 / 3 / 2015$ & 54.3 & 50.8 & & \\
\hline
\end{tabular}

\begin{tabular}{|l|l|l|l|l|l|l|}
\hline & & $22 / 3 / 2015$ & 45.7 & 49.2 & & \\
\hline \multirow{4}{*}{4} & $12 / 3 / 2015$ & 61.6 & 62.8 & & \\
\cline { 3 - 5 } & Ramanujar & $13 / 3 / 2015$ & 70.5 & 60.2 & \multirow{4}{*}{51.0} & \multirow{4}{*}{60.8} \\
\cline { 3 - 5 } & \begin{tabular}{c} 
College \\
\cline { 3 - 5 }
\end{tabular} & $14 / 3 / 2015$ & 57.7 & 62.8 & & \\
\hline & $15 / 3 / 2015$ & 65.4 & 57.2 & & \\
\hline
\end{tabular}

Noise exposures in sampling area from the urban sand silent zones are been distinguished and listed in the Table.6. The average noise level in the peak hours has been calculated and listed. It was observed from the study during the peak hours in the Silent zone the noise level exceeding the specified limits. It is necessary that quarry site must be located far away from the vicinity of residential area and green cover must be increased. Sound barriers must be provided mainly in the hospital areas and the hospital wards very close to quarry and highway area. The workers and people in the very close vicinity of quarry site can be provided with Personal Protective Equipment (PPE) ear muff etc. The hospital structure can rehabilitated with sound insulation to protect the patient from noise pollution. Low cost control measure is by increasing landscape and green cover in the area where noise pollution level is high. The government also must take measures to enforce noise pollution guidelines at least in the sensitive and residential areas so that the health impact of noise pollution can be mitigated or controlled.

\section{CONCLUSION}

Noise pollution study on the quarry site through some light on impact of noise pollution in the sensitive and residential zone. The health effects of the excess noise in the study area are high especially in the sensitive areas. The noise pollution level near the Tagore medical college found to high than prescribed guidelines as per CPCB. The other location the noise levels are within the limit. In the residential zone sampling the noise levels near highways are comparatively higher than the CPCB guidelines. Noise level in the sampling site 6 (Kandigai) is higher according to CPCB standards. The noise impact can be mitigated by increasing the green cover and strict enforcement of noise pollution guidelines by the authorities. To keep vigil on noise pollution it can be monitored periodically mainly in the residential and sensitive zones especially in the vicinity of quarry site.

\section{REFERENCES}

1. M.F.Ali, "Air Pollution: A case study on suspended air particulate matter at AmanPerdana, Klang, Selangor. Malaysia”. Greener Journal of science, Engineering and Technology Research, 3 (6), 186-194, 2013.

2. BhabanandaPhukan and KalyanKalita, "An Experimental Study of Noise Pollution InGauhati University Campus, Guwahati, Assam, India". International Journal of Environmental Sciences, 3(5), 1776-1786, 2013.

3. Gayatri Singh, Amit Pal, Rajeev K Niranjan and Manjesh Kumar., "Assessment of environmental impacts by mining activities: A case study from Jhansi open cast mining site Uttar Pradesh,India". Journal of Experimental Sciences, 1(1), 09-13, 2010.

4. V. Krishna Murthy, A.K. Majunder, S.N. Khanal and D.P. Subedi, "Assessment of Traffic Noise Pollution InBanepa, A Semi Urban Town of Nepal". Kathmandu University Journal of Science, Engineering and Technology, I(1), 01-09, 2007.

5. A.A. Muhammad, S.H. Ahmed, R.A. Muhammad, I.A. Qasi, "Determination of Total Suspended Particulate 
matter and heavy metals in ambient air of four cities of Pakistan”. Iranica J. Energy \&Environ., 2 (2): 128-132, 2011.

6. K.K. Panda, A.K. Swar, R.B. Panda and B.C. Mikeup, "Distribution of Respirable suspended particulate matter in ambient air and its impact on human health and remedial measures in Joda-Barbil region in India".South African Journal of Chemical Engineering, 18(1), 18-29, 2009.

7. B. Rajiv, "Assessment of Noise Pollution Indices in the city of Kolhapur, India". Procedia - social and behavioral sciences 37 , $448-457,2012$.

8. B.S.Bada, K.A. Olatunde, O.A. AKande, "Air quality Assessment in the Vicinity of Quarry site "Environment and Natural Resources Research";3(2), 111-118, 2013.

9. T. VidyaSagar and G. Nageswara Rao,"Noise Pollution Levels In Visakhapatnam City (India)". Journal of Environ. Science \&Engg.48(2), 139 - 142, 2006.

10. V. Nartey, J. Nanor and R. Klake,"Effects of Quarry Activities on some Selected Communities in the Lower ManyaKrobo District of the Eastern Region of Ghana".Atmospheric and Climate Sciences, 2(2) 362-372, 2012.doi: 10.4236/acs.2012.23032.

11. J.S. Sudarsan and S. Nithiyanantham, Study on Noise Pollution in and around SRM University Campus, South Asia(India). Advanced Science, Engineering and Medicine, 8(11), 896-905, 2016.DOI: https://doi.org/10.1166/asem.2016.1910.

12. CPCB (Central Pollution Control Board of India, 2009.

13. B. Griefahn, A. Marks, S. Robens, Noise emitted road road, rail, and air traffic and their effects on sleep", Journal of Sound and Vibration,.295, doi:10.1016/j.jsv.2005.12.052.

\section{AUTHOR PROFILE}

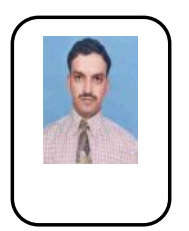

First author: Assistant Professor having more than 2 decade of teaching and 12 years of research experience. He published more than 35 articles in reputed journal and published 2 text books.

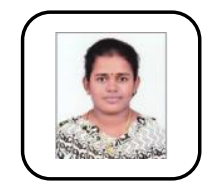

Second author: Working as Environmental consultan (Freelancer) in Chennai having research interest on pollution management.

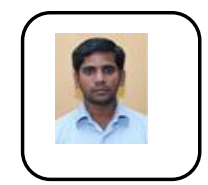

Third author: Professor having vast experience in teaching and research experience. He has published more than 75 articles in refereed journals and guiding PG and $\mathrm{PhD}$ students

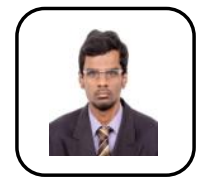

Forth author: Assistant Professor having more research interest on waste management and constructed wetlands for waste water treatment. He has 5 research papers in Scopus Indexed journals to his credit. He has attended several national and international conferences. 